\title{
Synthesis and Characterization of the Adducts of Morpholinedithioccarbamate Complexes of Oxovanadium (IV), Nickel(II), and Copper(II) with Piperidine and Morpholine
}

\author{
MOUSAMI SHARMA*, ANJU SHARMA, AND RENU SACHAR \\ Department of Chemistry, University of Jammu, Babasaheb Ambedkar Road, Jammu- \\ 180006, India \\ mousami.sharma@gmail.com
}

Received 02 November 2011; Accepted 07 January 2012

\begin{abstract}
A series of 1:1 adducts of bis(morpholinedithiocarbamato) complex of $\mathrm{VO}(\mathrm{IV}), 1: 1$ and 1:2 adducts of bis(morpholinedithiocarbamato) complexes of $\mathrm{Ni}(\mathrm{II})$ and $\mathrm{Cu}(\mathrm{II})$ with piperidine and morpholine have been synthesized and characterized by elemental analysis, molar conductance, magnetic susceptibility, IR, UV-Vis, and TGA/DTA techniques. Analytical data reveals that $\mathrm{VO}(\mathrm{IV})$ complex forms only 1:1 adducts with the formula [VO(morphdtc) $\left.{ }_{2} \mathrm{~L}\right] \cdot \mathrm{H}_{2} \mathrm{O}$ while $\mathrm{Ni}(\mathrm{II})$ and $\mathrm{Cu}(\mathrm{II})$ complexes form both $1: 1$ and 1:2 adducts with $1: 1$ adducts having general formula $\mathrm{Ni}(\text { morphdtc })_{2}$. $\mathrm{L}$ and $\mathrm{Cu}$ (morphdtc $)_{2}$. $\mathrm{L}$ and $1: 2$ adducts having general formula $\mathrm{Ni}(\text { morphdtc })_{2} \cdot \mathrm{L}_{2}$ and $\mathrm{Cu}(\text { morphdtc })_{2} \cdot \mathrm{L}_{2}$ (morphdtc $=$ morpholinedithiocarbamate, $\mathrm{L}=$ morpholine and piperidine). Antifungal activity of some complexes has been carried out against the fungal strain Fusarium oxysporium. Thermal studies indicate a continuous weight loss. A square pyramidal geometry has been proposed for the $1: 1$ adducts of $\mathrm{Ni}(\mathrm{II})$ and $\mathrm{Cu}(\mathrm{II})$ complexes while an octahedral geometry has been proposed for the 1:1 adducts of VO(IV) and for the 1:2 adducts of $\mathrm{Ni}(\mathrm{II})$ and $\mathrm{Cu}$ (II) complexes.
\end{abstract}

Keywords: morpholinedithiocarbamate, piperidine, morpholine.

\section{Introduction}

Dithiocarbamates are the half amides of dithiocarbonic acids and can function either as unidentate or bidentate chelating ligands ${ }^{1-4}$. The strong metal binding properties of the dithiocarbamates were recognized early by the virtue of insolubility of the metal salts and the capacity of the molecules to form chelate complexes. They are capable of stabilizing transition metals in a wide range of oxidation states and frequently stabilize the metal centre in an unusually high apparent formal oxidation state. In vast majority of instances, they act merely as non sterically demanding ancillary ligands ${ }^{\mathbf{5}, \mathbf{6}}$. These 1,1-dithiolato systems are of current interest due to their potential biological activity and practical applications in the 
fields of rubber technology and agriculture, in addition to general considerations of metalsulfur bonding and electron delocalization in transition metal complexes ${ }^{7-11}$. They have been successfully used as fungicides, pesticides, vulcanization accelerators, floatation agents and high pressure lubricants ${ }^{12}$. Moreover they act as therapeutic agents for alcoholism and metal intoxication $^{13,14}$. Now a days they have also been reported to treat acquired immune depressive syndrome and cancer ${ }^{15-17}$. In view of the diverse applications of the dithiocarbamates we have reported the synthesis and characterization of 1:1 and 1:2 adducts of some $3 \mathrm{~d}$ - transition metal dithiocarbamates with morpholine and piperidine.

\section{Experimental}

Morpholine (Fluka), and piperidine (SDS) were purified by distillation after keeping the bases over potassium hydroxide overnight. Metal analysis was done by reported methods ${ }^{\mathbf{1 8}}$. Carbon, hydrogen, and nitrogen analysis were performed by micro analytical methods. Molar conductivity in chloroform and DMF $\left(10^{-3} \mathrm{M}\right)$ at room temperature was measured using a Digital conductivity meter "Century CC 601" and a conductivity cell with a cell constant 1 . Magnetic susceptibility of the complexes was recorded at room temperature by VSM technique. IR spectra of the complexes over the region $4000-400 \mathrm{~cm}^{-1}$ were recorded on Perkin Elemer FTIR spectrophotometer using $\mathrm{KBr}$ disc. The electronic spectra of the complexes were recorded in the range $12500-40000 \mathrm{~cm}^{-1}$ on Systronics 119 UV-Visible spectrophotometer. Thermogravimetric analysis (TGA/DTA) of complexes was recorded on EXSTAR TG/DTA 6300 thermoanalyzer at the heating rate of $10^{\circ} \mathrm{C} / \mathrm{min}$. The antifungal activity of the complex was tested by Poisoned Food Technique against the pathogenic fungus, Fusarium oxysporium. All the experiments were carried out at room temperature.

\section{Preparation of Sodium Salt of Morpholine dithiocarbamate}

Morpholine $(8.7 \mathrm{~mL}, 0.1 \mathrm{~mole})$ and diethyl ether $(150 \mathrm{~mL})$ were taken in a round bottom flask and the contents were stirred for ten minutes. To this carbon disulfide $(6 \mathrm{~mL}, 0.1 \mathrm{~mole})$ was added dropwise with continuous stirring. During the course of the reaction, dithiocarbamic acid was formed to which concentrated solution of sodium hydroxide $(4 \mathrm{~g}$, 0.1 mole) was added slowly with continuous vigorous stirring for 4 hours. The sodium salt of morpholinedithiocarbamic acid formed was filtered out and washed with dry ether. The crude product was recrystallized from 2-propanol and dried in a vacuum desiccator.

\section{Preparation of bis(morpholinedithicarbamato) Complexes of $\mathrm{VO}(\mathrm{IV}), \mathrm{Ni}(\mathrm{II})$ and $\mathrm{Cu}(\mathrm{II})$}

Oxovanadium(IV), Nickel(II) and Copper(II) morpholinedithiocarbamate complexes were prepared by adding an aqueous solution of sodium salt of morpholinedithiocarbamate $(0.02$ mole) to an aqueous solution of $\mathrm{VOSO}_{4}\left(1.63 \mathrm{~g}, 0.01\right.$ mole), $\mathrm{NiCl}_{2} \cdot 6 \mathrm{H}_{2} \mathrm{O}(2.3771 \mathrm{~g}, 0.01$ mole) and $\mathrm{CuSO}_{4} .5 \mathrm{H}_{2} \mathrm{O}(2.49,0.01$ mole) respectively with stirring in $2: 1$ molar ratio. The $\mathrm{VO}(\mathrm{IV})$ and $\mathrm{Ni}(\mathrm{II})$ complexes formed were green in colour while $\mathrm{Cu}(\mathrm{II})$ complex obtained was brown in colour. The complexes were precipitated immediately which were filtered, washed several times with distilled water and dried in a vacuum desiccator.

\section{Preparation of 1:1 Adducts of bis(morpholinedithiocarbamato)VO(IV)}

The $1: 1$ adducts were obtained by stirring the ligand $(0.01$ moles $)$ and $\mathrm{VO}(\text { morphdtc })_{2}(0.01$ moles) in acetone for three hours. Green coloured precipitates of the adducts were filtered and dried in a vacuum desiccator over anhydrous calcium chloride.

Preparation of 1:1 Adducts of bis(morpholinedithiocarbamato)Ni(II) 
1:1 Addition complexes of bis(morpholinedithiocarbamato)Ni(II) with piperidine and morpholine were prepared by refluxing bis(morpholinedithiocarbamato)Ni(II) (0.01 moles) with the ligand $(0.01$ moles) in dimethylformamide for one hour. The contents were kept overnight when shining green coloured crystals of the adducts were obtained. The adducts were filtered, washed and dried in vacuo.

\section{Preparation of 1:1 Adducts of bis(morpholinedithiocarbamato)Cu(II)}

The 1:1 adducts of bis(morpholinedithiocarbamato) $\mathrm{Cu}(\mathrm{II})$ were prepared by refluxing bis(morpholinedithiocarbamato) $\mathrm{Cu}$ (II) (0.01 moles) with the ligand in dimethylformamide for about two hours. The contents were kept as such overnight when shining brown crystals of the adducts were obtained which were filtered, washed and dried in vacuo.

\section{Preparation of 1:2 Adducts of bis(morpholinedithiocarbamato)Ni(II)}

Bis(morpholinedithiocarbamato)Ni(II) (0.01 moles) was dissolved in dimethylformamide and to it the ligand ( 0.02 moles) was added. The contents were refluxed for one hour and kept overnight undisturbed when shining dark green crystals of the adducts were obtained which were filtered, dried and stored in a vacuum desiccator.

\section{Preparation of 1:2 Adducts of bis(morpholinedithiocarbamato)Cu(II)}

Bis(morpholinedithiocarbamato) $\mathrm{Cu}$ (II) (0.01 moles) was dissolved in dimethylformamide and the ligand ( 0.02 moles) was added to it. The contents were refluxed for about two hours. The resulting reaction mixture was kept undisturbed overnight when shining blackish brown crystals of the adduct were formed which were filtered, dried and stored in a vacuum desiccator over calcium chloride.

\section{Results and Discussion}

The analytical and physico-chemical results show that 1:1 adducts formed have the general formulae $\left[\mathrm{VO}\left(\mathrm{S}_{2} \mathrm{CNC}_{4} \mathrm{H}_{8} \mathrm{O}\right)_{2} \cdot \mathrm{L}\right] \cdot \mathrm{H}_{2} \mathrm{O}, \mathrm{Ni}\left(\mathrm{C}_{4} \mathrm{H}_{8} \mathrm{ONCS}_{2}\right)_{2} \cdot \mathrm{L}$ and $\mathrm{Cu}_{(}\left(\mathrm{C}_{4} \mathrm{H}_{8} \mathrm{ONCS}_{2}\right)_{2} . \mathrm{L}$ and the 1:2 adducts formed have general formulae $\mathrm{Ni}\left(\mathrm{C}_{4} \mathrm{H}_{8} \mathrm{ONCS}_{2}\right)_{2} \cdot \mathrm{L}_{2}$ and $\mathrm{Cu}\left(\mathrm{C}_{4} \mathrm{H}_{8} \mathrm{ONCS}_{2}\right)_{2}$. $\mathrm{L}_{2}$. All the complexes are coloured, stable in air and soluble in some common organic solvents. The molar conductivity of $1: 1$ and $1: 2$ adducts of $\mathrm{Ni}$ (morphdtc $)_{2}$ and $\mathrm{Cu}$ (morphdtc) $)_{2}$ measured in $10^{-3} \mathrm{M}$ chloroform solution are found to be in the range of $10-28 \mathrm{ohm}^{-1} \mathrm{~cm}^{2}$ $\mathrm{mol}^{-1}$ and $9-42 \mathrm{ohm}^{-1} \mathrm{~cm}^{2} \mathrm{~mol}^{-1}$ respectively (Table 1). The molar conductance measurements of the adducts $\mathrm{VO}(\text { morphdtc })_{2}$ were carried out in dimethylformamide and the values of their millimolar solutions were found to be 48 and $56 \mathrm{ohm}^{-1} \mathrm{~mole}^{-1} \mathrm{~cm}^{2}$ (Table 1). These values observed for all these adducts are lower than the values which can be expected for uni-univalent electrolytes in these solvents suggesting that these complexes are undissociated and non-electrolytic in nature.

\section{Magnetic Measurements}

Magnetic susceptibility measurements carried out at room temperature indicate that the 1:1 adducts of bis(morpholinedithiocarbamato)Ni(II) are diamagnetic in nature exhibiting magnetic moments around zero which is in agreement with the magnetic moment values observed for many low spin square pyramidal complexes of Ni(II) while 1:2 adducts of bis(morpholinedithiocarbamato)Ni(II) are paramagnetic exhibiting magnetic moment values of 3.09 and 3.16 B.M. which is in agreement with the magnetic moment values observed for octahedral complexes of $\mathrm{Ni}(\mathrm{II})$. The $1: 1$ and 1:2 adducts of bis(morpholinedithiocarbamato) $\mathrm{Cu}$ (II) exhibit magnetic moment values in the range 1.83 to 1.93 B.M. These values are slightly higher than the spin only value and are in accordance with square pyramidal geometry for the 1:1 adducts and octahedral geometry for the 1:2 
adducts. The magnetic moments of the adducts of bis(morpholinedithiocrbamato)VO(IV) complex are found to be 1.82 and 1.86 B.M. The values are in accordance with the octahedral geometry and monomeric nature of oxovanadium(IV) complexes ${ }^{19}$. The higher value of magnetic moment may be due to the orbital contribution ${ }^{20}$. The magnetic moments of all the adducts are given in table 1 .

Table 1. Analytical and Physical data of the Adducts.

\begin{tabular}{|c|c|c|c|c|c|c|c|c|}
\hline \multirow{2}{*}{$\begin{array}{l}\dot{2} \\
\dot{z}\end{array}$} & \multirow{2}{*}{ Complex } & \multirow{2}{*}{$\begin{array}{c}\text { Molar } \\
\text { Conduc } \\
\text { tivity } \\
(\mathrm{Ohm}- \\
1 \mathrm{~cm} 2 \\
\text { mol-1) }\end{array}$} & \multirow{2}{*}{$\begin{array}{c}\text { Magnetic } \\
\text { Moments } \\
\text { (B.M.) (300 } \\
\text { K) }\end{array}$} & \multicolumn{5}{|c|}{ Analysis Found (Calculated) } \\
\hline & & & & C & $\mathrm{H}$ & $\mathrm{N}$ & S & M \\
\hline 1 & $\begin{array}{l}\mathrm{VO}(\text { morphdtc })_{2} \text {.morp } \\
\text { holine }] . \mathrm{H}_{2} \mathrm{O}\end{array}$ & 56 & 1.82 & $\begin{array}{l}33.15 \\
(33.86)\end{array}$ & $\begin{array}{r}4.92 \\
(5.44)\end{array}$ & $\begin{array}{l}8.11 \\
(8.46)\end{array}$ & $\begin{array}{l}25.01 \\
(25.8)\end{array}$ & $\begin{array}{c}9.89 \\
(10.28)\end{array}$ \\
\hline 2 & $\begin{array}{l}{\left[\mathrm{VO}(\text { morphdtc })_{2} \text {.pipe }\right.} \\
\text { ridine }] . \mathrm{H}_{2} \mathrm{O}\end{array}$ & 48 & 1.86 & $\begin{array}{l}36.12 \\
(36.42)\end{array}$ & $\begin{array}{l}5.25 \\
(5.87)\end{array}$ & $\begin{array}{c}8.15 \\
(8.49)\end{array}$ & $\begin{array}{l}25.32 \\
(25.9)\end{array}$ & $\begin{array}{c}9.92 \\
(10.32)\end{array}$ \\
\hline 3 & $\begin{array}{l}\mathrm{Ni}(\text { morphdtc })_{2} \cdot \text { morph } \\
\text { oline }\end{array}$ & 15 & Diamagnetic & $\begin{array}{l}35.11 \\
(35.76)\end{array}$ & $\begin{array}{r}5.02 \\
(5.32)\end{array}$ & $\begin{array}{l}8.23 \\
(8.94)\end{array}$ & $\begin{array}{l}26.94 \\
(27.25)\end{array}$ & $\begin{array}{r}12.04 \\
(12.48)\end{array}$ \\
\hline 4 & $\underset{\text { dine }}{\mathrm{Ni}(\text { morphdtc })_{2} \cdot \text { piperi }}$ & 15 & Diamagnetic & $\begin{array}{l}37.96 \\
(38.48)\end{array}$ & $\begin{array}{c}5.21 \\
(5.77)\end{array}$ & $\begin{array}{r}8.32 \\
(8.97)\end{array}$ & $\begin{array}{l}27.01 \\
(27.36)\end{array}$ & $\begin{array}{r}12.16 \\
(12.53)\end{array}$ \\
\hline 5 & $\begin{array}{l}\mathrm{Ni}(\text { morphdtc })_{2} \cdot(\text { morp } \\
\text { holine })_{2}\end{array}$ & 10 & 3.16 & $\begin{array}{l}38.27 \\
(38.79)\end{array}$ & $\begin{array}{c}6.43 \\
(6.79)\end{array}$ & $\begin{array}{r}10.99 \\
(11.18)\end{array}$ & $\begin{array}{c}25.11 \\
(25.56)\end{array}$ & $\begin{array}{c}10.21 \\
(10.52)\end{array}$ \\
\hline 6 & $\begin{array}{l}\mathrm{Ni}(\text { morphdtc })_{2} \cdot(\text { piper } \\
\text { idine })_{2}\end{array}$ & 28 & 3.09 & $\begin{array}{c}42.92 \\
(43.41)\end{array}$ & $\begin{array}{r}6.49 \\
(6.87)\end{array}$ & $\begin{array}{r}9.87 \\
(10.13)\end{array}$ & $\begin{array}{l}22.72 \\
(23.15)\end{array}$ & $\begin{array}{c}9.98 \\
(10.59)\end{array}$ \\
\hline 7 & $\begin{array}{l}\mathrm{Cu}(\text { morphdtc })_{2} \text {.morp } \\
\text { holine }\end{array}$ & 11 & 1.83 & $\begin{array}{l}34.63 \\
(35.39)\end{array}$ & $\begin{array}{r}4.86 \\
(5.27)\end{array}$ & $\begin{array}{r}8.39 \\
(8.85)\end{array}$ & $\begin{array}{l}29.56 \\
(29.97)\end{array}$ & $\begin{array}{l}13.02 \\
(13.39)\end{array}$ \\
\hline 8 & $\underset{\text { dine }}{\mathrm{Cu}(\text { morphdtc })_{2} \text {.piperi }}$ & 42 & 1.85 & $\begin{array}{l}37.67 \\
(38.08)\end{array}$ & $\begin{array}{c}5.21 \\
(5.71)\end{array}$ & $\begin{array}{r}8.43 \\
(8.89)\end{array}$ & $\begin{array}{l}26.78 \\
(27.08)\end{array}$ & $\begin{array}{l}12.95 \\
(13.44)\end{array}$ \\
\hline 9 & $\begin{array}{l}\mathrm{Cu}(\text { morphdtc })_{2} \cdot(\text { morp } \\
\text { holine })_{2}\end{array}$ & 9 & 1.93 & $\begin{array}{l}38.01 \\
(38.45)\end{array}$ & $\begin{array}{r}5.89 \\
(6.05)\end{array}$ & $\begin{array}{l}9.97 \\
(9.97)\end{array}$ & $\begin{array}{l}22.74 \\
(22.78)\end{array}$ & $\begin{array}{l}11.28 \\
(11.31)\end{array}$ \\
\hline 10 & $\begin{array}{l}\mathrm{Cu}(\text { morphdtc })_{2} \cdot \text { (piper } \\
\text { idiane })_{2}\end{array}$ & 23 & 1.89 & $\begin{array}{r}42.86 \\
(43.02)\end{array}$ & $\begin{array}{r}6.55 \\
(6.81)\end{array}$ & $\begin{array}{c}9.92 \\
(10.04)\end{array}$ & $\begin{array}{l}22.63 \\
(22.95)\end{array}$ & $\begin{array}{l}11.08 \\
(11.39)\end{array}$ \\
\hline
\end{tabular}


Table 2. Important IR spectral bands $\left(\mathrm{cm}^{-1}\right)$ and their assignment.

\begin{tabular}{|l|c|c|c|c|c|}
\hline S.No. & Complex & $v(\mathrm{~N}-\mathrm{H})$ & $v(\mathrm{C}-\mathrm{N})$ & $v(\mathrm{C}-\mathrm{S})$ & $v(\mathrm{M}-\mathrm{S})$ \\
\hline 1. & {$\left[\mathrm{VO}(\text { morphdtc })_{2} \cdot\right.$ morpholine $] . \mathrm{H}_{2} \mathrm{O}$} & 3292 & 1462 & 1114 & 414 \\
\hline 2. & {$\left[\mathrm{VO}(\text { morphdtc })_{2} \cdot\right.$ piperidine $] . \mathrm{H}_{2} \mathrm{O}$} & 3261 & 1458 & 1112 & 412 \\
\hline 3. & $\mathrm{Ni}(\text { morphdtc })_{2} \cdot$ morpholine & 3274 & 1491 & 1011 & 419 \\
\hline 4. & $\mathrm{Ni}(\text { morphdtc })_{2} \cdot$ piperidine & 3256 & 1497 & 1011 & 420 \\
\hline 5. & $\mathrm{Ni}(\text { morphdtc })_{2} \cdot(\text { morpholine })_{2}$ & 3250 & 1497 & 1013 & 420 \\
\hline 6. & $\mathrm{Ni}(\text { morphdtc })_{2} \cdot(\text { piperidine })_{2}$ & 3245 & 1495 & 1025 & 418 \\
\hline 7. & $\mathrm{Cu}(\text { morphdtc })_{2} \cdot$ morpholine & 3253 & 1441 & 1010 & 417 \\
\hline 8. & $\mathrm{Cu}(\text { morphdtc })_{2} \cdot$ piperidine & 3242 & 1485 & 1009 & 420 \\
\hline 9. & $\mathrm{Cu}(\text { morphdtc })_{2} \cdot(\text { morpholine })_{2}$ & 3250 & 1485 & 1009 & 419 \\
\hline 10. & $\mathrm{Cu}(\text { morphdtc })_{2} \cdot(\text { piperidine })_{2}$ & 3221 & 1438 & 1022 & 424 \\
\hline
\end{tabular}

\section{Infrared Spectra}

The IR spectra of the adducts of $\mathrm{VO}(\text { morphdtc })_{2}, \mathrm{Ni}$ (morphdtc $)_{2}$ and $\mathrm{Cu}(\text { morphdtc })_{2}$ exhibit bands characteristic of the presence of coordinated dithiocarbamate group and the ligand molecules. A single band of strong intensity was observed in the range 1025-1009 $\mathrm{cm}^{-1}$ which may be attributed to $v(\mathrm{C}-\mathrm{S})$ vibration. A positive shift of $10-35 \mathrm{~cm}^{-1}$ in comparison to the corresponding band in the free ligand indicates that the dithiocarbamate ligand coordinates with the metal through sulphur atoms. The presence of an only $\mathrm{C}-\mathrm{S}$ band can be due to the greatest contribution of the resonance form $\left(\mathrm{RN}^{+} \mathrm{CS}_{2}{ }^{-}\right)$in the adducts and the complex thus suggesting symmetrical bidentate binding of the dithiocarbamato moiety ${ }^{21-23}$. A new band of medium to strong intensity was observed in the region $424-412 \mathrm{~cm}^{-1}$, which may be assigned to $v(\mathrm{M}-\mathrm{S})$ stretching mode. A strong band in the region 1497-1438 $\mathrm{cm}^{-1}$ associated with "thiuride" vibration is attributed to $v(\mathrm{C}-\mathrm{N})$ vibration and indicates the partial double bond character of the $\mathrm{C}-\mathrm{N}$ bond ${ }^{24}$. The $\mathrm{NH}$ vibrations of the coordinating secondary amines were observed in the region $3292-3221 \mathrm{~cm}^{-1}$ showing a negative shift of $160-150 \mathrm{~cm}^{-1}$ upon coordination with the metal. Apart from this, the infrared spectra of the adducts of $\mathrm{VO}$ (morphdtc $)_{2}$ also exhibit a strong band at $996-970 \mathrm{~cm}^{-1}$ which is attributed to the terminal $\mathrm{V}=\mathrm{O}$ bond. A comparison of the infrared spectral data of $\mathrm{VO}(\text { morphdtc })_{2}$ complex with its adducts reveals that $\mathrm{V}=\mathrm{O}$ band in the parent complex $\left(1000-980 \mathrm{~cm}^{-1}\right)$ gets displaced to lower frequencies $\left(990-970 \mathrm{~cm}^{-1}\right)$ in the adducts ${ }^{19}$. This displacement can be attributed to the electronic donation of the base to the vanadium $(\mathrm{N}-\mathrm{V})$, which increases the electron density on the metal d-orbitals, and consequently the $\mathrm{p}_{\pi}-\mathrm{d}_{\pi}$ donation from oxygen atom to vanadium is expected to be reduced.

\section{Electronic Spectra}

The electronic spectra of the 1:1 and 1:2 adducts of $\mathrm{Ni}$ (morphdtc $)_{2}$ and $\mathrm{Cu}(\text { morphdtc })_{2}$ were recorded in chloroform while the electronic spectra of the $1: 1$ adducts of $\mathrm{VO}$ (morphdtc) were recorded in dimethylformamide in the range $12500-40000 \mathrm{~cm}^{-1}$. The adducts of bis(morpholinedithiocarbamato)oxovanadium(IV) show three bands in the range 13870$14310 \mathrm{~cm}^{-1}, 16092-17065 \mathrm{~cm}^{-1}$ and $22080-22420 \mathrm{~cm}^{-1}$ which are assigned to $\mathrm{e} \leftarrow \mathrm{b}_{2}\left(\mathrm{v}_{1}\right), \mathrm{b}_{1}$ 
$\leftarrow \mathrm{b}_{2}\left(\mathrm{v}_{2}\right)$ and $\mathrm{a}_{1} \leftarrow \mathrm{b}_{2}\left(\mathrm{v}_{3}\right)$ transitions respectively. These bands are characteristic of oxovanadium(IV) complexes in octahedral environment ${ }^{19,20}$.

Table 3. Electronic spectra of the adducts.

\begin{tabular}{|c|c|c|c|c|}
\hline S.No. & Complex & $v_{1}$ & $v_{2}$ & $v_{3}$ \\
\hline 1. & {$\left[\mathrm{VO}(\text { morphdtc })_{2} \cdot \text { morpholine }\right]_{2} \mathrm{H}_{2} \mathrm{O}$} & 13870 & 16092 & 22080 \\
2. & {$\left[\mathrm{VO}(\text { morphdtc })_{2} \cdot\right.$ piperidine $] \mathrm{H}_{2} \mathrm{O}$} & 14310 & 17065 & 22420 \\
\hline 3. & $\mathrm{Ni}(\text { morphdtc })_{2} \cdot$ morpholine & 16826 & 24865 & - \\
\hline 4. & $\mathrm{Ni}(\text { morphdtc })_{2} \cdot$ piperidine & 16798 & 24993 & - \\
\hline 5. & $\mathrm{Ni}(\text { morphdtc })_{2} \cdot(\text { morpholine })_{2}$ & 11245 & 17844 & 26990 \\
\hline 6. & $\mathrm{Ni}(\text { morphdtc })_{2} \cdot(\text { piperidine })_{2}$ & 11321 & 17242 & 26998 \\
\hline 7. & $\mathrm{Cu}(\text { morphdtc })_{2} \cdot$ morpholine & 16542 & - & - \\
\hline 8. & $\mathrm{Cu}(\text { morphdtc })_{2} \cdot$ piperidine & 16748 & - & - \\
\hline 9. & $\mathrm{Cu}(\text { morphdtc })_{2} \cdot(\text { morpholine })_{2}$ & 15312 & - & - \\
\hline 10. & $\mathrm{Cu}(\text { morphdtc })_{2} \cdot(\text { piperidine })_{2}$ & 15425 & - & - \\
\hline
\end{tabular}

The 1:1 adducts of $\mathrm{Ni}(\text { morphdtc })_{2}$ show a broad, slightly asymmetric absorption band centred around $24000 \mathrm{~cm}^{-1}$. This transition of very high intensity can be assigned to ${ }^{1} \mathrm{~A}_{1} \rightarrow{ }^{1} \mathrm{E}$ transition $\left(v_{2}\right)$. The shoulder around $17000 \mathrm{~cm}^{-1}$ can be assigned to spin allowed orbitally forbidden transition $\left(v_{1}\right)$ i.e., ${ }^{1} \mathrm{~A}_{1} \rightarrow{ }^{1} \mathrm{~B}_{1}\left(\mathrm{~d}_{\mathrm{z}}{ }^{2} \rightarrow \mathrm{d}_{\mathrm{x}-\mathrm{y}}{ }^{2}\right)^{25}$. The appearance of strong, asymmetric absorption band of very high intensity suggests that square pyramidal geometry can be preferred over trigonal bipyramidal geometry for these adducts. In addition absorption bands observed in the region $33000-41000 \mathrm{~cm}^{-1}$ can be assigned to $\mathrm{M} \rightarrow \mathrm{L}$ charge transfer transitions. 1:2 Adducts of $\mathrm{Ni}(\text { morphdtc })_{2}$ show three broad bands in the region 11000, $17000,27000 \mathrm{~cm}^{-1}$. The band seen around $11,000 \mathrm{~cm}^{-1}$ is assigned to ${ }^{3} \mathrm{~A}_{2 \mathrm{~g}}(\mathrm{~F}) \rightarrow{ }^{3} \mathrm{~T}_{2 \mathrm{~g}}(\mathrm{~F})\left(\mathrm{v}_{1}\right)$ transition while the bands observed around $17000 \mathrm{~cm}^{-1}$ and $28000 \mathrm{~cm}^{-1}$ are assigned to ${ }^{3} \mathrm{~A}_{2 \mathrm{~g}}$ $\rightarrow{ }^{3} \mathrm{~T}_{1 \mathrm{~g}}(\mathrm{~F})\left(\mathrm{v}_{2}\right)$ and ${ }^{3} \mathrm{~A}_{2 \mathrm{~g}}(\mathrm{~F}) \rightarrow{ }^{3} \mathrm{~T} 1 \mathrm{~g}(\mathrm{P})\left(\mathrm{v}_{3}\right)$ transitions respectively and are suggestive of octahedral geometry around $\mathrm{Ni}(\mathrm{II})$ metal ion ${ }^{26}$.

1:1 Adducts of $\mathrm{Cu}$ (morphdtc $)_{2}$ show a broad band with maximum intensity appearing around $16000 \mathrm{~cm}^{-1}$ which can be assigned to $\mathrm{d}_{\mathrm{xz}}, \mathrm{d}_{\mathrm{yz}} \rightarrow \rightarrow_{\mathrm{dx}-\mathrm{y}}^{2}\left(\mathrm{v}_{1}\right)$, suggesting a square pyramidal geometry around $\mathrm{Cu}$ (II) ion. A weak shoulder around $11000 \mathrm{~cm}^{-1}$ is also shown by these adducts $^{27}$. On the other hand 1:2 adducts of $\mathrm{Cu}$ (morphdtc) $)_{2}$ show one broad absorption band in the region $14000-16000 \mathrm{~cm}^{-1}$. The observed band is the average of two transitions $\mathrm{d}_{\mathrm{xy}} \rightarrow{ }_{\mathrm{dx}}^{2} \mathrm{y}^{2}$ and $\mathrm{d}_{\mathrm{xz}}, \mathrm{d}_{\mathrm{yz}} \rightarrow{ }_{\mathrm{dx}}^{2}{ }^{2} \mathrm{y}$. The band $\mathrm{d}_{\mathrm{xz}}, \mathrm{d}_{\mathrm{yz}} \rightarrow{ }_{\mathrm{dx}-\mathrm{y}}^{2}$ is generally regarded as "copper band" ${ }^{\prime 28}$. These transitions correspond to $t_{2 g} \rightarrow e_{g}$ transition in a regular octahedral complex.

\section{Thermal Studies}

The TG curves of the complexes (Table 4) were recorded in the temperature range 30$1000^{\circ} \mathrm{C}$. The DTA curve of 1:1 adduct of $\mathrm{VO}(\text { morphdtc })_{2}$ with morpholine (Graph 1) shows 
a loss of a water molecule at about $149^{\circ} \mathrm{C}$ which corresponds to a weight loss of $3.62 \%$. In the TG curve a weight loss of $17.36 \%$ at about $151^{\circ} \mathrm{C}$ is observed which may be due to the loss of one morpholine molecule. Then a continuous weight loss is observed due to the loss of two morphdtc ligands and the resultant weight corresponds to the formation of a stable oxide $\mathrm{VO}_{2}$ at $988^{\circ} \mathrm{C}$.

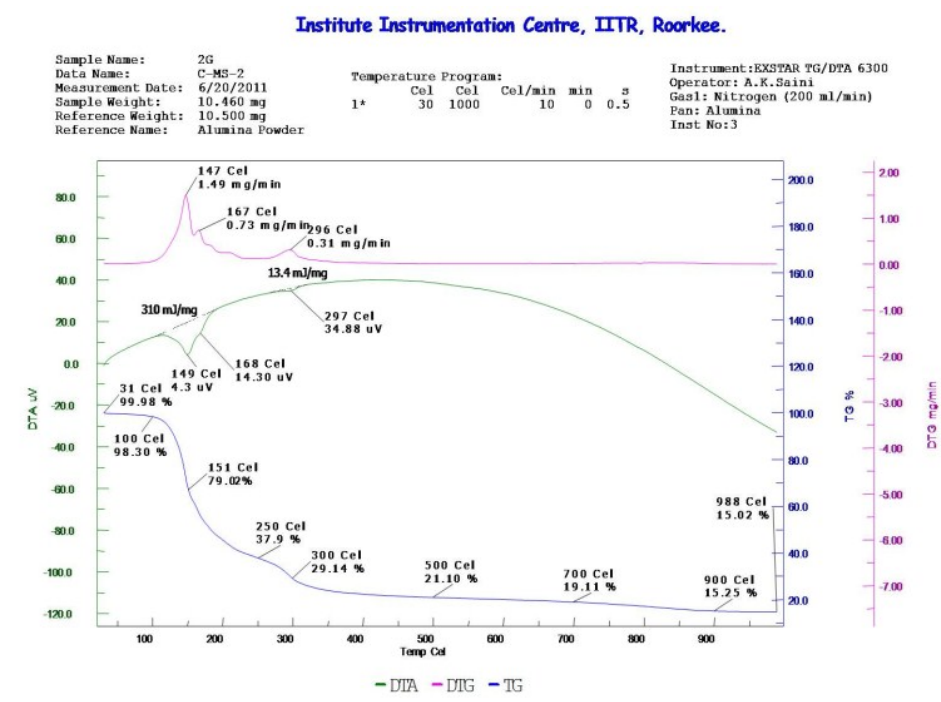

\section{Graph 1}

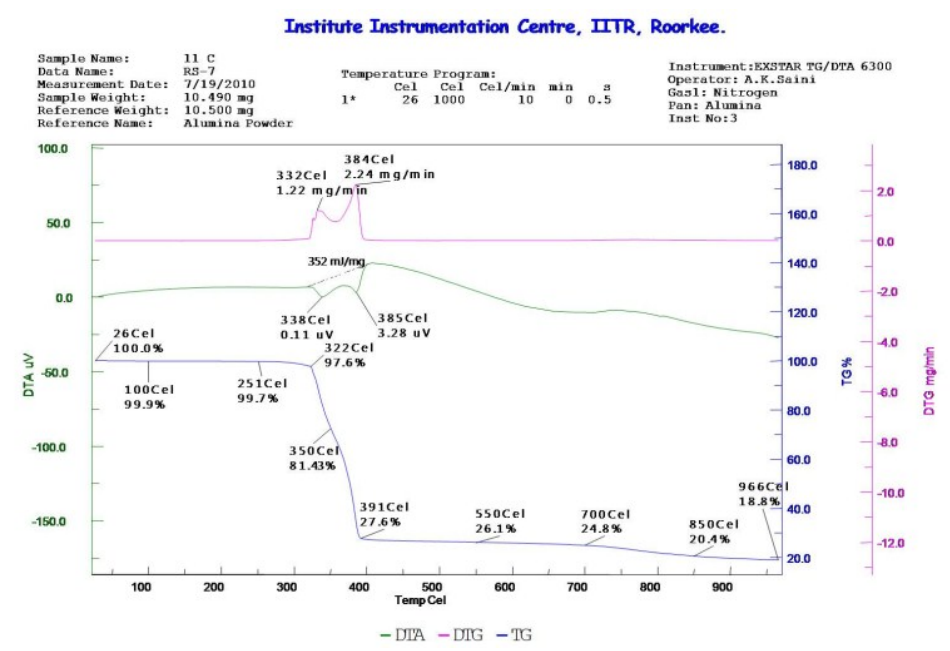

\section{Graph 2}

The TG curve of the 1:1 and 1:2 adducts of $\mathrm{Ni}(\text { morphdtc })_{2}$ with piperidine were investigated. The 1:1 adduct shows a weight loss of $18.57 \%$ at about $350^{\circ} \mathrm{C}$ due to the loss of one piperidine molecule. Then a continuous weight loss of $62.63 \%$ is observed due to the loss of $\mathrm{C}_{10} \mathrm{H}_{16} \mathrm{~N}_{2} \mathrm{O}_{2} \mathrm{~S}_{3}$ moiety until a stable sulphide NiS is formed at $996^{\circ} \mathrm{C}$ (Graph 2). On the other hand $1: 2$ complex shows the loss of two piperidine molecules at about $350^{\circ} \mathrm{C}$ corresponding 
to the weight loss of $30.43 \%$. Then a continuous weight loss of $52.42 \%$ is observed due to the loss of $\mathrm{C}_{10} \mathrm{H}_{16} \mathrm{~N}_{2} \mathrm{O}_{2} \mathrm{~S}_{3}$ moiety and the resultant weight corresponds to the formation of stable sulphide $\mathrm{NiS}$ at around $966^{\circ} \mathrm{C}$ (Graph 3)

Table 4. Thermal degradation of the adducts.

\begin{tabular}{|c|c|c|c|c|c|}
\hline S.No. & Complex & $\begin{array}{c}\text { Dec. } \\
\text { Temp. }\left({ }^{\circ} \mathrm{C}\right)\end{array}$ & $\begin{array}{l}\text { \% Weight } \\
\text { loss obs. } \\
\text { (calc.) }\end{array}$ & $\begin{array}{l}\text { Residue } \\
\text { compd. }\end{array}$ & $\begin{array}{l}\text { Weght } \\
\text { found } \\
\text { (calc.) }\end{array}$ \\
\hline 1. & {$\left[\mathrm{VO}(\text { morphdtc })_{2} \cdot\right.$ morpholine $] \cdot \mathrm{H}_{2} \mathrm{O}$} & 988 & $\begin{array}{c}84.98 \\
(83.27)\end{array}$ & $\mathrm{VO}_{2}$ & $\begin{array}{r}15.02 \\
(16.72)\end{array}$ \\
\hline 2. & $\mathrm{Ni}(\text { morphdtc })_{2} \cdot$ piperidine & 966 & $\begin{array}{c}81.20 \\
(80.68)\end{array}$ & $\mathrm{NiS}$ & $\begin{array}{c}18.80 \\
(19.32)\end{array}$ \\
\hline 3. & $\mathrm{Ni}(\text { morphdtc })_{2} \cdot(\text { piperidine })_{2}$ & 965 & $\begin{array}{c}82.85 \\
(83.66)\end{array}$ & $\mathrm{NiS}$ & $\begin{array}{l}17.15 \\
(16.34)\end{array}$ \\
\hline 4. & $\mathrm{Cu}(\text { morphdtc })_{2} \cdot$ morpholine & 990 & $\begin{array}{c}79.96 \\
(79.87)\end{array}$ & $\mathrm{CuS}$ & $\begin{array}{l}20.04 \\
(20.13)\end{array}$ \\
\hline 5. & $\mathrm{Cu}(\text { morphdtc })_{2} \cdot(\text { morpholine })_{2}$ & 989 & $\begin{array}{c}84.73 \\
(83.04)\end{array}$ & $\mathrm{CuS}$ & $\begin{array}{c}15.27 \\
(16.96)\end{array}$ \\
\hline
\end{tabular}

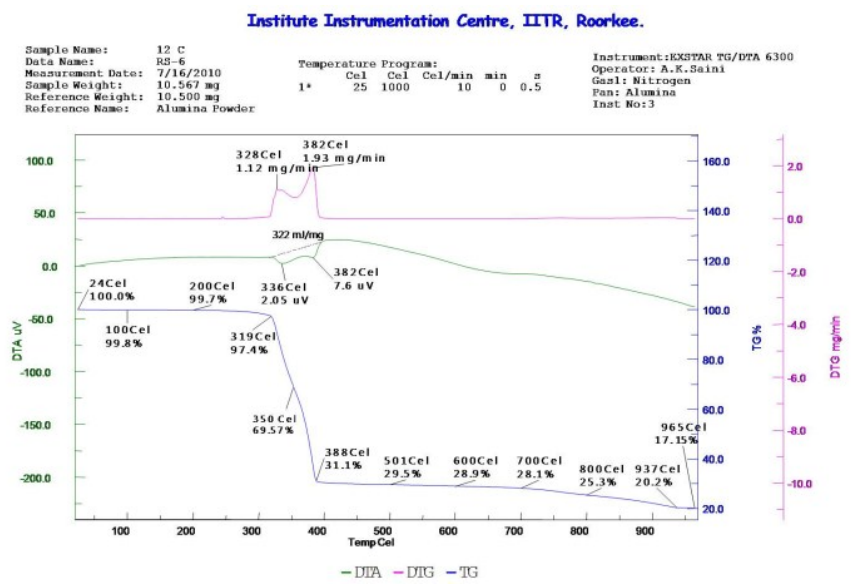

Graph 3

The TG curve for the complex $\mathrm{Cu}$ (morphdtc) ${ }_{2}$ (morpholine) (Graph 4) shows a weight loss of $18.89 \%$ at $300^{\circ} \mathrm{C}$ which may be due to the loss of one morpholine molecule. Then a continuous weight loss of $61.07 \%$ is observed which may be due to the loss of $\mathrm{C}_{10} \mathrm{H}_{16} \mathrm{~N}_{2} \mathrm{O}_{2} \mathrm{~S}_{3}$ moiety till a stable sulphide $(\mathrm{CuS})$ is formed at about $990^{\circ} \mathrm{C}$. On the other hand in the TG curve of the 1:2 complex, Cu(morphdtc) $)_{2}$ (morpholine) $)_{2}$, (Graph 5) a weight loss of $31.01 \%$ may occur at about $329^{\circ} \mathrm{C}$ due to the loss of two morpholine molecules. Then a continuous 
weight loss of $53.72 \%$ is observed which may be due to the loss of $\mathrm{C}_{10} \mathrm{H}_{16} \mathrm{~N}_{2} \mathrm{O}_{2} \mathrm{~S}_{3}$ and a stable sulphide $(\mathrm{CuS})$ is formed at about $989^{\circ} \mathrm{C}$.

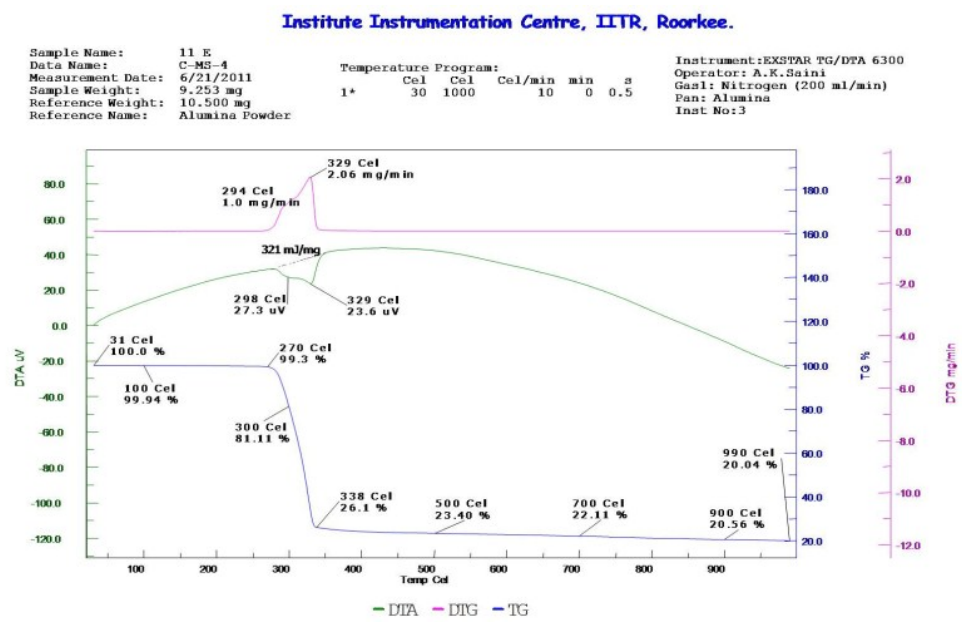

Graph 4

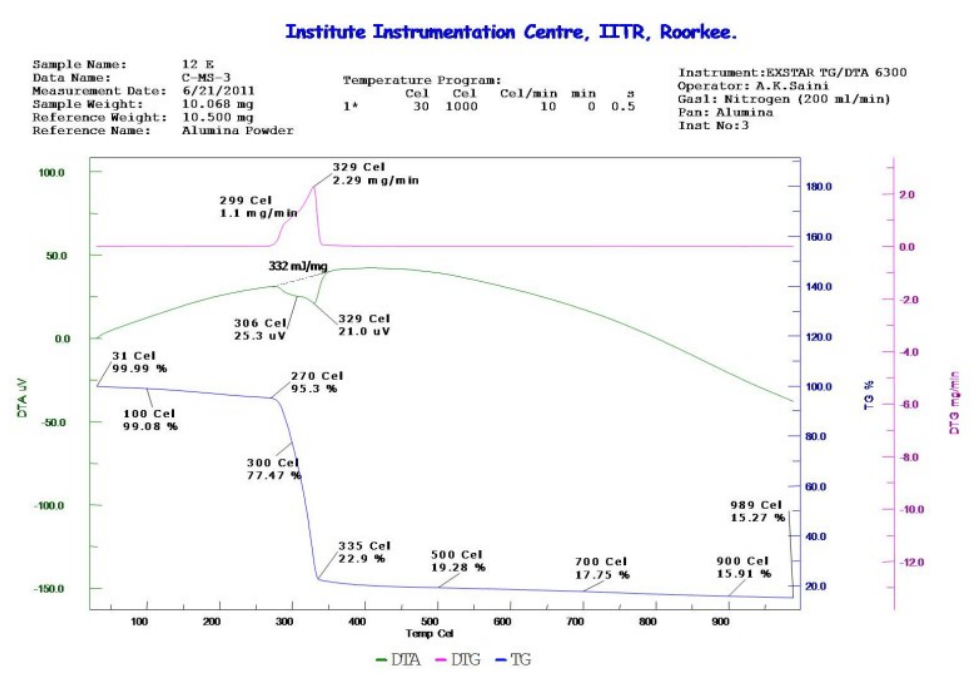

Graph 5

\section{Biological Studies}

The antifungal activity of the complex was tested by Poisoned Food Technique against the pathogenic fungus, Fusarium oxysporium. The test solutions were prepared by dissolving the compounds in chloroform and dimethylformamide. The test solutions were mixed in the PDA and poured in the petriplates in sterilized conditions inside the Laminar flow. After solidification, the plates were inoculated with seven days old culture of pathogen, Fusarium 
oxysporium by placing $2 \mathrm{~mm}$ bit in the centre of the plates. The inoculated plates were incubated at $27{ }^{\circ} \mathrm{C}$ for 4 days. The linear growth of fungus in controlled manner was recorded at different concentrations of the complexes. The growth inhibition of Fusarium oxysporium over control was calculated (Table 5) and it shows that on increasing the concentration of the complexes, the colony diameter of the fungus decreases and hence percent inhibition increases (Fig. 1). The increase in antifungal activity is due to faster diffusion of metal complexes as a whole through the cell membrane or due to combined activity effect of the metal and the ligand.

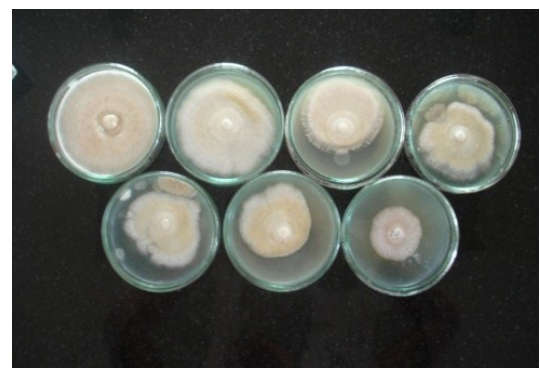

(a)

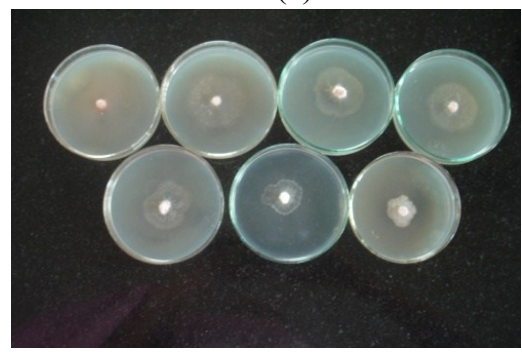

(c)

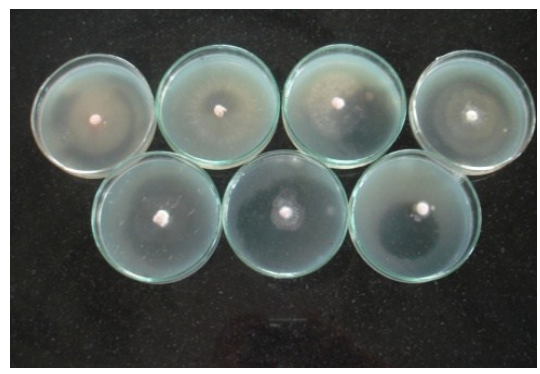

(b)

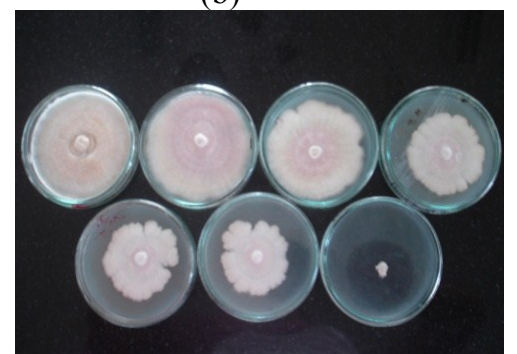

(d)

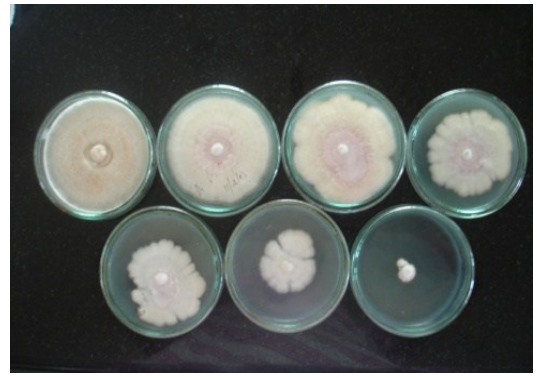

(e)

Fig.1 .Antifungal activity of the adducts (a) $\left[\mathrm{VO}(\text { morphdtc })_{2}\right.$ (morpholine) $] \cdot \mathrm{H}_{2} \mathrm{O}$, (b) $\mathrm{Ni}$ (morphdtc $)_{2}$ (morpholine), (c) Ni(morphdtc $)_{2}(\text { morpholine })_{2}$, (d) $\mathrm{Cu}$ (morphdtc $)_{2}$ (morpholine), and (e) $\mathrm{Cu}(\text { morphdtc })_{2}$ (morpholine $)_{2}$.

Such increased activity of the metal complexes can be explained on the basis of Overtone's concept $^{29}$ and Tweedy's chelation theory ${ }^{30}$. The lipid membrane that surrounds the cell favours passage of only lipid soluble materials due to liphophilicity being an important factor which controls the antifungal activity. On chelation, the polarity of the metal ion will be reduced to a greater extent due to overlap of the ligand orbital and partial sharing of the positive charge of the metal ion with donor group. 
Table 5. Antifungal activities of some adducts.

\begin{tabular}{|c|c|c|c|c|}
\hline S.No. & Complex & $\begin{array}{l}\text { Concenteration } \\
(\mathrm{ppm})\end{array}$ & $\begin{array}{l}\text { Colony } \\
\text { Diameter } \\
(\mathrm{mm})\end{array}$ & $\begin{array}{c}\% \\
\text { Inhibition } \\
\mathrm{I}=[(\mathrm{C}- \\
\mathrm{T}) / \mathrm{C}] \times 100\end{array}$ \\
\hline 1. & {$\left[\mathrm{VO}(\text { morphdtc })_{2} \cdot\right.$ morpholine $] \cdot \mathrm{H}_{2} \mathrm{O}$} & $\begin{array}{c}50 \\
100 \\
150 \\
200 \\
250 \\
500\end{array}$ & $\begin{array}{c}81.5 \\
78.5 \\
68.5 \\
58 \\
42 \\
40\end{array}$ & $\begin{array}{c}9.44 \\
12.77 \\
23.88 \\
35.55 \\
53.33 \\
55.55\end{array}$ \\
\hline 2. & $\mathrm{Ni}(\text { morphdtc })_{2}$.piperidine & $\begin{array}{c}50 \\
100 \\
150 \\
200 \\
250 \\
500\end{array}$ & $\begin{array}{c}58 \\
51 \\
40 \\
33 \\
26.5 \\
15\end{array}$ & $\begin{array}{c}4.9 \\
16.39 \\
34.42 \\
45.90 \\
56.55 \\
75.40\end{array}$ \\
\hline 3. & $\mathrm{Ni}(\text { morphdtc })_{2} \cdot(\text { piperidine })_{2}$ & $\begin{array}{c}50 \\
100 \\
150 \\
200 \\
250 \\
500\end{array}$ & $\begin{array}{l}54 \\
42 \\
39 \\
35 \\
25 \\
24 \\
\end{array}$ & $\begin{array}{l}11.47 \\
31.14 \\
36.06 \\
42.62 \\
59.01 \\
60.65\end{array}$ \\
\hline 4. & $\mathrm{Cu}(\text { morphdtc })_{2} \cdot$ morpholine & $\begin{array}{c}50 \\
100 \\
150 \\
200 \\
250 \\
500\end{array}$ & $\begin{array}{c}89 \\
73 \\
58.5 \\
54 \\
49 \\
7\end{array}$ & $\begin{array}{c}1.11 \\
18.88 \\
35 \\
40 \\
45.55 \\
92.22\end{array}$ \\
\hline 5. & $\mathrm{Cu}(\text { morphdtc })_{2} \cdot(\text { morpholine })_{2}$ & $\begin{array}{c}50 \\
100 \\
150 \\
200 \\
250 \\
500\end{array}$ & $\begin{array}{l}80 \\
77 \\
63 \\
54 \\
43 \\
18\end{array}$ & $\begin{array}{c}11.11 \\
14.44 \\
30 \\
40 \\
52.22 \\
80\end{array}$ \\
\hline
\end{tabular}

\section{Conclusions}

An octahedral geometry has been proposed for the $1: 1$ adducts of $\mathrm{VO}$ (morphdtc $)_{2}$ and for the $1: 2$ adducts of $\mathrm{Ni}(\text { morphdtc })_{2}$ and $\mathrm{Cu}(\text { morphdtc })_{2}$ while a square pyramidal geometry has been suggested for the 1:1 adducts of both $\mathrm{Ni}(\text { morphdtc })_{2}$ and $\mathrm{Cu}(\text { morphdtc })_{2}$. Moreover the antifungal activity of the adducts show a linear relationship with the concenteration.

\section{References}

1. Kanamori K, Nishida K, Miyata N, Okamoto K, Miyoshi Y, Tamura A and Sakurai H, J. Inorg. Biochem., 2001, 86, 649.

2. Djordjevic C, Leeand M and Sinn E, Inorg. Chem., 1989, 28, 719. 
3. Kana A T, Hibbert T G, Mahon M F, Molly K C, Parkin I P and Price L S, Polyhedron, 2001, 20, 2989.

4. Law N A, Dietzsch W and Duffy N V, Polyhedron, 2003, 22, 3423.

5. Hogarth G, Prog. Inorg. Chem., 2005, 53, 71.

6. Bond A M and Martin R L, Coord. Chem. Rev., 1984, 54, 23.

7. Kalia S B, Kaushal G, Sharma D K and Verma B C, Synth. and React. Inorg., Met.-Org. and Nano-Met. Chemistry, 2005, 35, 181.

8. Cervantes G, Moreno V, Molins E and Miravitlles C, Metal based Drugs, 1997, 4, 317.

9. Mauclaire, Laurent and Berthommier, Eric FR Appl., 2000, 15, 57; Chem. Abstr., 2002, 137, 14843m.

10. Neves A, Rossi L M, Bortoluzzi A J, Mangrich A S, Haase W and Werner R, J. of Brazil. Chem. Soc., 2001, 12, 747; Chem. Abstr., 2002, 136, 144232b.

11. Arora C L and Kaur J, Asian J. Chem., 1993, 5, 473.

12. Coucouvanis D, Prog. Inorg. Chem., 1970, 11, 235.

13. Thorn G D and Ludwig R A, The Dithiocarbamates and Related Compounds, NewYork, 1962.

14. Golcu A, Trans. Met. Chem., 2006, 31, 405.

15. Reisinger E C, Kern P, Ernst M, Bock P, Flad H D and Dietrich M, Inhibition of HIV progression by Dithiocarb. German DTC study Group, Lancet, 1990, 335, 679.

16. Gandara D R, Perez E A, Weibe V and De Gregorio M W, Semin. Oncol., 1991, 18, 49.

17. Kim C H, Kim J H, Xu J, Hsu C Y and Ahn Y S, Blackwell Synergy: J. Neurochem., 1999, 72, 1586.

18. Jeffery G H, Bassett J, Mehdham J and Denny R C, Vogel's Text Book of Quantitative Chemical Analysis, $5^{\text {th }}$ Edition Longman Group UK Ltd., 1989, 455, 462, 472.

19. Doadrio A L, Sotelo J and Ruano A F, Quim. Nova, 2002, 25.

20. Aswar A S, Bansod A D, Aswale S R and Mamdlik P R, Ind. J. Chem., 2004, 43(A), 1892.

21. Golding R M, Harris C M, Jessop K J and Tennant W, Aust. J. Chem., 1972, 25, 2567.

22. Faretti A C, Forghieri F, Giusti A, Preti C and Tosi G, Inorg. Chim. Acta., 1984, 86, 127.

23. Bonati F and Ugo R, J. Organometallic Chem., 1967, 10, 257.

24. Bradley D C and Gitlitz M H, J. Chem. Soc.(A), 1969, 1152.

25. Preer J and Gray H B, J. Am. Chem. Soc., 1965, 2771.

26. Lever A B P, Inorganic Electronic Spectroscopy, Elsevier, Amsterdam, 1968.

27. Duggan M, Ray N and Hathaway B J, J. Chem. Soc. Dalton, 1980, 1342.

28. Hathaway B J, Billing D E, Nicholls P and Procter I M, J. Chem. Soc. (A), 1969, 319.

29. Dharamraj N, Viswanathamurthi $P$ and Natarajan K, Trans. Met. Chem., 2001, 26, 105.

30. Mishra L and Singh V K. Ind. J. Chem., 1993, 32A, 446. 


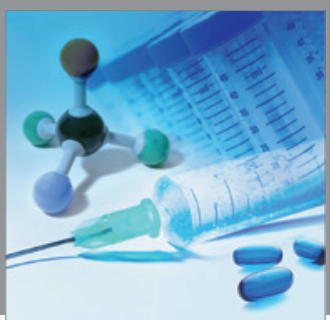

International Journal of

Medicinal Chemistry

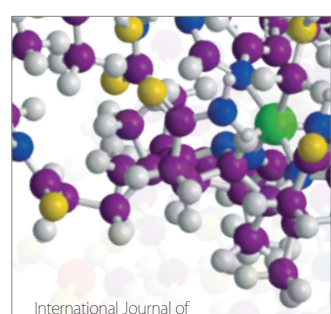

Carbohydrate Chemistry

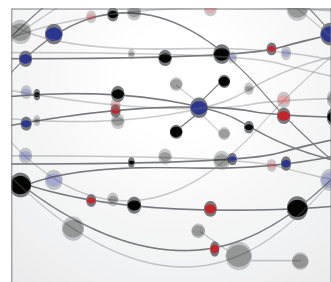

The Scientific World Journal
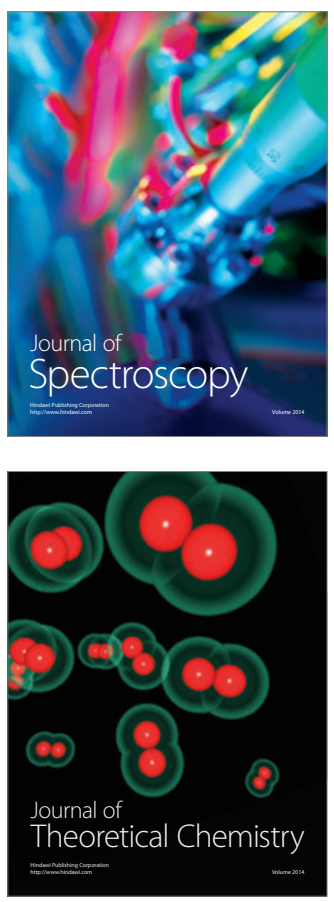
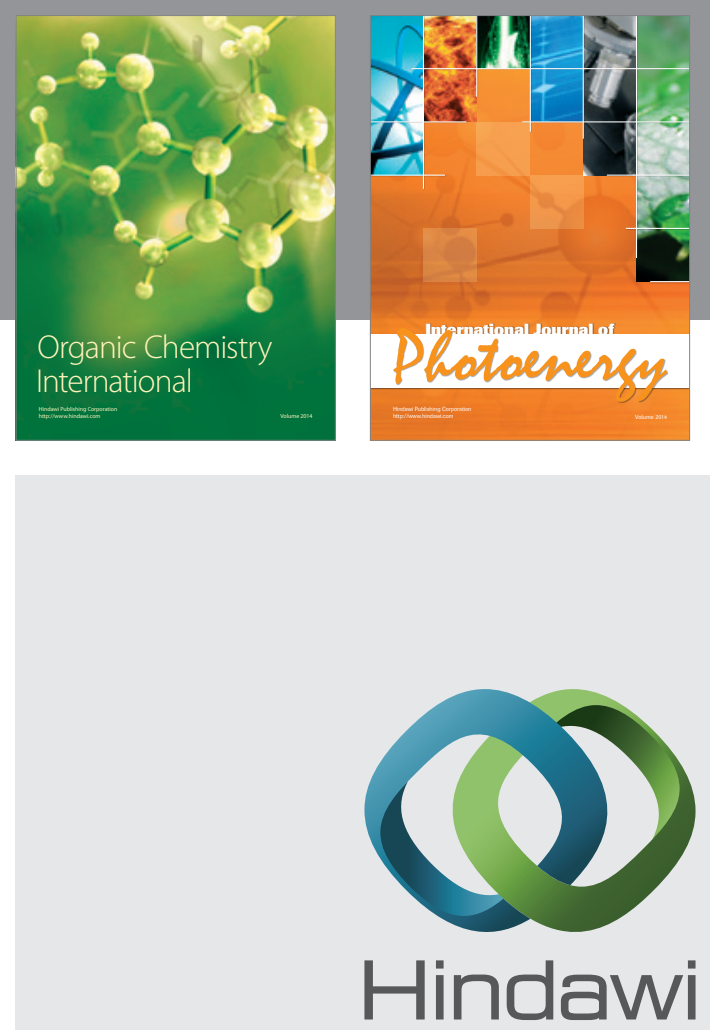

Submit your manuscripts at

http://www.hindawi.com
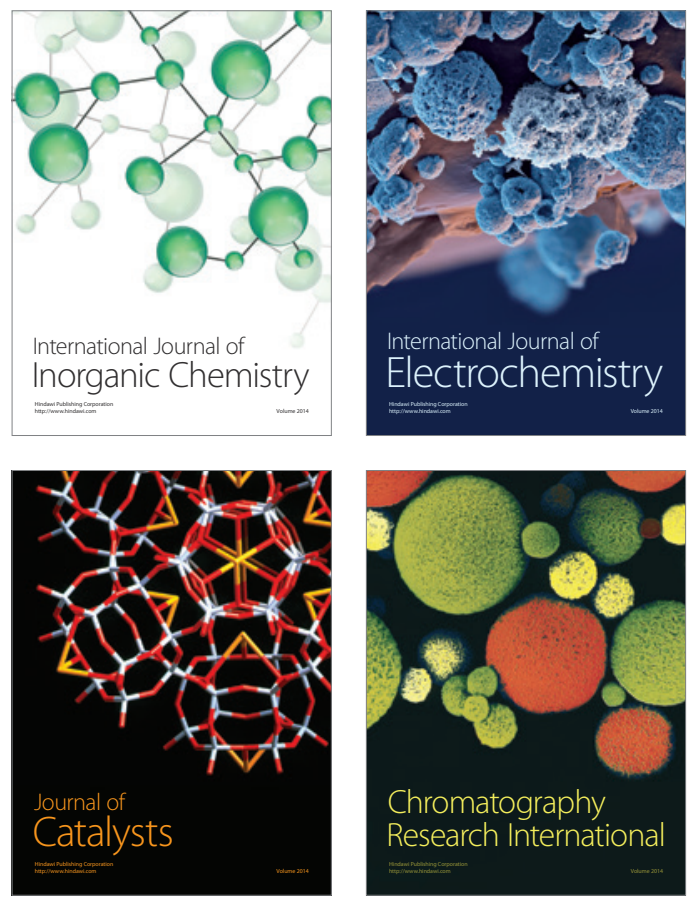
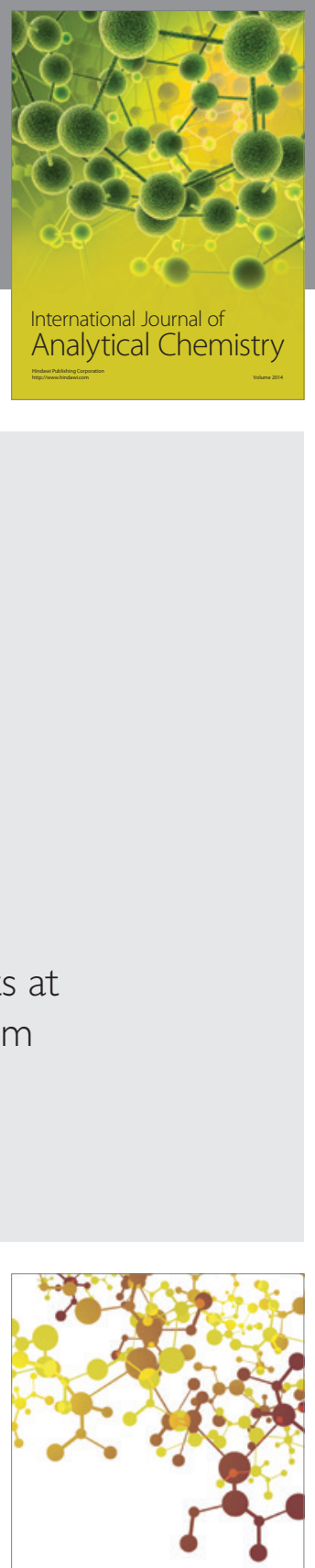

Journal of

Applied Chemistry
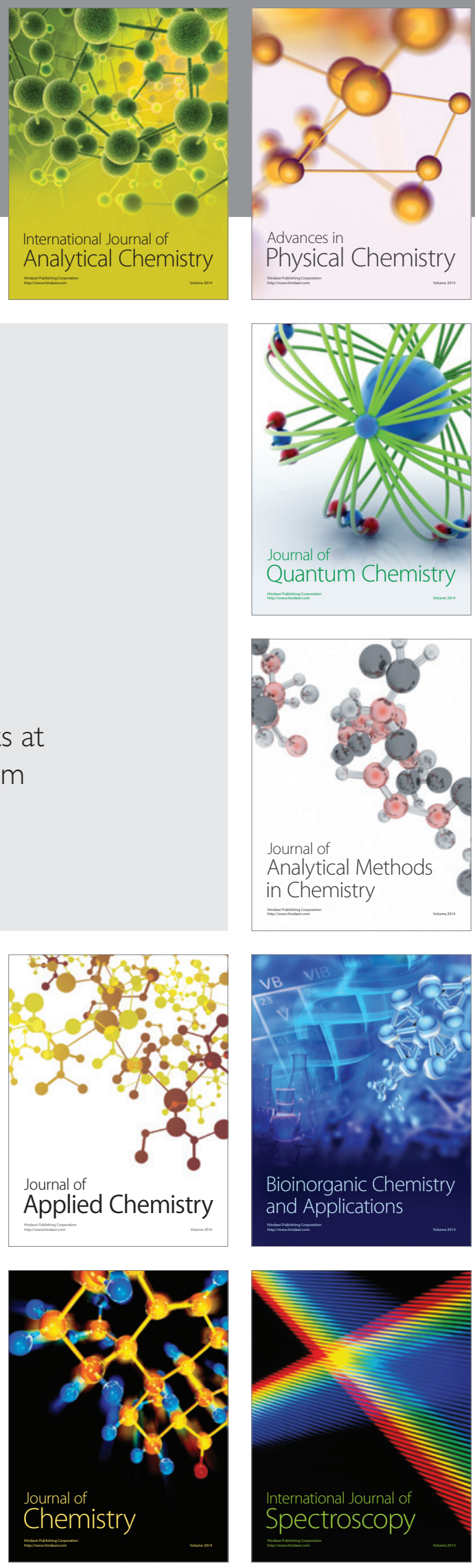